\title{
Intention to Purchase Halal Cosmetics on Indonesian Women
}

\author{
Saifudin $^{1}$, Rosana Eri Puspita ${ }^{2}$, Ahmad Minan Zuhri ${ }^{3}$, Mudzakir Muhlisin ${ }^{4}$, Mochlasin $^{5}$ \\ \{saifudin@iainsalatiga.ac.id ${ }^{1}$ \}
}

IAIN Salatiga ${ }^{12345}$

\begin{abstract}
The purpose of this paper is to investigate the factors that influence the intention to buy halal cosmetics. This paper investigates the impact of subjective norms, attitudes, and religiosity on the intention to buy halal-certified cosmetics. The sample data used in this study were 202 respondents in Indonesia. SPSS is used to test the significance of the influence of independent variables. The test results show that attitudes, subjective norms, and religiosity have a positive and significant influence on buying intentions of halal-certified cosmetics. Muslim entrepreneurs can estimate the behavior of potential customers through this paper. As for academics, this paper can be used for further research by integrating religiosity in the Theory of Reason Action as a predictor influencing intention to purchase. Empirically this research is useful to increase understanding of the halal industry and consumer behavior.
\end{abstract}

Keywords: subjective norms, attitudes, religiosity, intention to buy, halal cosmetics

\section{Introduction}

The halal industry in the world has enormous potential. This is because the total Muslim population in the world is 1.6 billion. With this sizeable Muslim population, the Muslim market has become an emerging market[1]. In addition to the large number, the awareness of the Muslim community towards the halal industry has also increased. In many parts of the world in the world, exhibitions of halal products are often held. Awareness can also be seen from the public interest in halal certification listed on the products to be purchased.

In the country of Indonesia itself, the total Muslim population is 207,176,162 people [2]. This amount is classified as a large number so that the Muslim community becomes the majority in Indonesia[3]. For the world, the Muslim population is the largest compared to the Muslim population in other countries. The movement of Muslim communities in Indonesia is also dynamic. Hijrah movements in halal products are in demand in many Sectors.

In Indonesia, the cosmetics market is also a product that has good prospects. This is because the total population of women is $117,674,318$ people[2]. With such a large population of women, the potential for the cosmetics market is large to work on. Halal cosmetics also have a good opportunity to enter the Indonesian market. Not only in terms of the population of Muslim women, but the shift in halal lifestyle also strengthens the opportunity for a strong halal cosmetics to dominate the market. 
However, this condition is not balanced by the high awareness of the Indonesian Muslim community to use halal cosmetics [4]. With these conditions, it is very necessary to know what mystical factors influence purchase intention among Indonesian Muslim women.

According to data from LPPOM MUI, the number of products that have obtained MUI halal certificates since 2014 from the food group and food raw materials is 355,260 (49\%), cosmetics as much as 26,958 (6\%), medicines (including herbs and supplements) as much as $4,750(1 \%)$, flavor, seasoning, fragrance as much as $(25 \%)$, and other products as much as $95,124(19 \%)[5]$.

This research is expected to have benefits. For cosmetic entrepreneurs, this research can help to estimate the behavior of potential customers through this paper. For academics, this paper can be used for further research by integrating religiosity in the Theory of Reason Action as a predictor influencing intention to purchase. Empirically this research is useful to increase understanding of the halal industry and consumer behavior.

New things in this research are the integration of religiosity on the established theory of reason Action. The idea of integration of this variable is the social conditions in Indonesia that are predominantly Muslim citizens who should apply halal certification in the use of many products, including cosmetics.

\section{Literature Review}

\subsection{Halal Cosmetic}

In the last ten years, cosmetics sales increased because many people began to care about beauty [6]. This condition causes cosmetic sales in the world to increase. However, this awareness of beauty has not been matched by the awareness of the Muslim community to prefer halal cosmetics [4].

The discussion of the cosmetics industry covers many disciplines, from consumer understanding, cosmetic safety, environmental impacts to social impacts [7]. For the Muslim community, halal is the main issue discussed in examining a product, including cosmetics. This halal concerns the ingredients, the process of making the product, to the transaction when selling it.

\subsection{Purchase Intention}

The intention is one predictor of behavior[8], so discussions about individual intentions are important to be carried out in the realm of marketing science. This intention is interpreted as a decision in behaving both consciously and unconsciously, which is influenced by several stimuli. Grand theories that discuss intentions include theory planned behavior (TPB) and Theory of Reason Action (TRA). These two theories belong to established theories.

In TRA, the intention is influenced by two predictors, namely attitude toward behavior and subjective norm[9]. The more mature behavior theory development triggers the Theory of Planned Behavior, which is the development of the Theory of Reason Action. In the Theory of Planned Behavior, the intention is influenced by three predictors, namely attitude, subjective norm, and perceived behavior control[10], [11].

In this study, purchase intention is measured by several indicators. These indicators are ready to buy halal certified cosmetic products, prefer to buy halal certified cosmetic products, 
willingness to buy halal certified cosmetics even if the brands are not popular, and willingness to buy halal certified cosmetic products even though more expensive.

\subsection{Subjective Norm}

Subjective norm is defined as a self-concept to the pressure of social norms so that it can influence or not influence behavior[12]. In TRA and TPB theory, the subjective norm is a variable that influences behavioral intention[11], [13], [14]. This is because subjective norms are stimuli received by individuals from the surrounding environment, such as neighbors, peers, and friends[15].

Social norms are divided into two, namely injunctive norms and descriptive norms[16]. Social norms referred to in TPB are injunctive norms, i.e., norms that are approved or disapproved in a community. At the same time, a descriptive norm is a behavior carried out by certain groups of people.

In this study, the subjective norm is measured by three indicators. The indicators are that most people think it's better to use halal-certified cosmetics, family members prefer halalcertified cosmetics, and recommendations from friends to use halal-certified cosmetics.

\subsection{Attitude}

Attitude is a variable that is often discussed in behavioral research[17] because it is a strong predictor in the formation of behavioral intention[18]. Attitude on the individual will have an impact on emotional and cognitive[19].

At the individual level, changes in behavior will change, along with changes in attitude[20]. If the attitude is difficult to change, then the behavior will be difficult to change. In other words, changing attitudes will cause the behavior to change[21] so that for marketers who want to change their purchase intention, they must first change the attitude of the consumer.

In this study, attitude is measured by three indicators. These indicators are a good idea with halal certification, prefer halal-certified cosmetics products than not, and think halalcertified cosmetic products have good quality.

\subsection{Religiosity}

Religiosity is defined as the level of individual confidence in his religion and reflected in the pattern of his daily life. In some cases, religiosity influences intention directly or indirectly. Religiosity influences attitude and intention[22] because this variable is used as a reference in making decisions for individuals.

In this study, religiosity is measured by three indicators. These indicators are religious belief under the whole perspective, religious belief affects all matters in life, and religion is essential in answering the problem of life.

\subsection{Hypothesis Development}

Subjective norms have been investigated as variables that have a significant influence in influencing the purchase intention of halal products[23]. From some established literature that subjective norms have a positive and significant effect on intention, the first hypothesis in this study was compiled.

H10 : There is no positive and significant effect on subjective norms on purchase 
intentions

H1a : There is a positive and significant effect on subjective norms on purchase intentions

In many kinds of literature, attitude has a positive and significant effect on intention[24], [25]. From some of the literature, the second hypothesis was compiled in this study.

H20 : There were no positive and significant effects on attitudes toward purchase intentions

$\mathrm{H} 2 \mathrm{a} \quad$ : There is a positive and significant influence on the attitude towards purchase intentions

Religiosity has a positive and significant influence on the purchase intention of halal products[22]. From these studies, the third hypothesis in this study was compiled.

H30 : There is no positive and significant influence on religiosity on purchase intentions

H3a : There is a positive and significant influence on religiosity on purchase intentions

\section{Method}

The population in this study were women as cosmetic users. The sampling technique was done by purposive sampling, which is sampling using certain criteria [26]. There are two criteria used in this sampling. First, respondents are women as representations of cosmetic users. Second, respondents are Muslim. The instrument in this study used an online questionnaire. A total of 202 respondents were selected on condition that they must meet two criteria. The data regarding the demographics of respondents are presented in Table 1.

\begin{tabular}{lc}
\multicolumn{2}{c}{ Table 1. Demographic Information } \\
\hline \multicolumn{1}{c}{ Demographic } & Percentage \\
\hline Age & \\
$17-20$ & 63.4 \\
$21-25$ & 30.7 \\
$26-30$ & 2.5 \\
$31-35$ & 0.5 \\
$36-40$ & 2.0 \\
$41-45$ & 1.0 \\
& \\
Last Education & \\
Under High School & \\
High School & 4.5 \\
Diploma & 3.5 \\
Bachelor & 38.1 \\
Postgraduate & 53.5 \\
& 0.5
\end{tabular}




\begin{tabular}{lc} 
Job & \\
Tourism service sector & 0.5 \\
Government officer & 3.0 \\
Financial service sector & 3.0 \\
Personal service sector & 0.5 \\
Manufacture sector & 4.5 \\
Trade sector & 10.4 \\
Fram sector & 1.5 \\
Student & 76.7 \\
& \\
Income per month & \\
$<2.000 .000$ IDR & 81.2 \\
2.000.000 IDR -5.000.000 IDR & 16.3 \\
5.000.001 IDR - 10.000.000 IDR & 1.5 \\
$>10.000 .000$ IDR & 1.0 \\
\hline \multicolumn{2}{c}{ Source: Data processed 2020 }
\end{tabular}

Based on Table 1, it can be seen that the respondents in this study consisted of 202 respondents who were all women. Meanwhile, according to age, respondents in this study were dominated by respondents aged 17-25 years, as much as $94 \%$. If seen from the last education of the respondents, it was dominated by respondents with $53.5 \% \mathrm{~S} 1$ education. When viewed in terms of employment, the respondents selected were dominated by respondents who were students as much as $76.7 \%$ and had an average income of fewer than 2 million rupiahs per month, which was $81.2 \%$.

The questionnaire was prepared by providing a five-point Likert scale answer choice. The Likert scale used consists of 1 (strongly disagree) to 5 (strongly agree). Validity and reliability testing was also conducted in this study to test the research instruments used. The results of testing the validity and reliability are presented in Table 2 and Table 3.

Table 2. The Result of KMO and Bartlett of Sphericity

\begin{tabular}{lc}
\hline Testing & Value \\
\hline Sample Adequacy KMO & 0.904 \\
Bartlett of Sphericity & 0.000 \\
\hline \multicolumn{2}{r}{ Source: Data processed 2020}
\end{tabular}

From the KMO and Bartlett of Sphericity testing, it can be seen that the KMO value is 0.904, which means the value is better. While the Bartlett of Spherecity value is equal to 0,000 , which means, the test results are significant. From testing this validity, it can be stated that the research instrument is valid.

Table 3. Convergent Validity and Reliability Test

\begin{tabular}{lr}
\hline Item & Loading \\
\hline Subjective Norm (CR=0.846) & \\
Most close people think it's better to use halal-certified cosmetics & 0.840 \\
Family members prefer halal-certified cosmetics & 0.747
\end{tabular}


Attitude $(\mathrm{CR}=\mathbf{0 . 9 2 7})$

Halal certification in cosmetics is a good idea

Prefer halal-certified cosmetics products than not

Think halal-certified cosmetic products have good quality

\section{Religiosity $(\mathrm{CR}=\mathbf{0 . 8 4 6})$}

Religious beliefs underlie the whole perspective

Religious beliefs affect all matters in life

Religion is essential in answering the problems of life

Purchase Intention $(\mathrm{CR}=\mathbf{0 . 8 5 3})$

Ready to buy halal certified cosmetic products

Prefer to buy halal certified cosmetic products

Will buy halal-certified cosmetics even if the brands are not popular

Will buy halal-certified cosmetic products even though more expensive

Table 3 illustrates the reliability of the instrument by showing the results of the Cronbach alpha value. From this test, it can be seen that the Cronbach alpha value for the subjective norm variable is 0.846 , the attitude variable is 0.927 , the religiosity variable is 0.846 , and the purchase intention variable is 0.853 . If you see a Cronbach alpha that exceeds 0.6 , it can be stated that this research instrument is reliable.

There are three variables in this study. Measurement of variable subjective norms is carried out using three indicators. First, the thoughts of people around respondents about cosmetic products that are halal certified are better. Second, the respondent's family members who choose halal cosmetic products. And finally, the respondent's friends who recommend halal cosmetic products.

There are three variables used to measure attitudes. First, addressing that the use of halal cosmetic products is a good idea. Second, the attitude of choosing halal cosmetic products over non-halal ones. And thirdly, the idea that halal cosmetic products have good quality.

The measurement of the religiosity variable is also measured by three indicators. The first indicator is the understanding that religious beliefs underlie the whole perspective. Second, the understanding that religious beliefs affect all matters in life. And third, the understanding that religion is essential in answering the problems of life.

The measurement of the purchase intention variable is carried out using four indicatorsthe first indicator, Ready to buy halal certified cosmetic products. Second, Prefer to buy halal certified cosmetic products. Third, the willingness to buy halal-certified cosmetics even if the brands are not popular. And fourth, willingness to buy halal-certified cosmetic products even though they are more expensive.

Hypothesis testing is done by regression testing using the SPSS program. This regression test aims to examine the effect of subjective norm variables on purchase intention, attitude on purchase intention, and religiosity on purchase intention. 


\section{Result And Discussion}

\subsection{Result}

The test used to prove the hypothesis in this study is a regression test. This test aims to measure the effect of exogenous variables on endogenous variables. This test is carried out with the help of the SPSS program.

\begin{tabular}{|c|c|c|c|}
\hline & SN to PI & AT to PI & RG to PI \\
\hline \multicolumn{4}{|c|}{ Determinant Coefficient and Adjusted $R$} \\
\hline $\mathrm{R}$ & 0.622 & 0.656 & 0.575 \\
\hline $\mathrm{R} 2$ & 0.386 & 0.431 & 0.330 \\
\hline Adjusted R Square & 0.383 & 0.428 & 0.327 \\
\hline \multicolumn{4}{|c|}{ Standardized Coefficient Beta } \\
\hline $\mathrm{T}$ & 11.221 & 12.301 & 9.927 \\
\hline Sig. & 0.000 & 0.000 & 0.000 \\
\hline \multicolumn{4}{|l|}{ Result of $F$ test } \\
\hline $\mathrm{F}$ & 125.906 & 151.305 & 98.537 \\
\hline Sig. & 0.000 & 0.000 & 0.000 \\
\hline
\end{tabular}

The first hypothesis testing shows that the value of $\mathrm{R}$ is 0.622 , the value of $\mathrm{R}$ Square is 0.386 , and the adjusted $\mathrm{R}$ Square value is 0.383 . From the value of $\mathrm{R}$ Square, it can be interpreted that $39 \%$ of purchase intention is influenced by subjective norm variables. In other words, $61 \%$ of behavioral intention is influenced by other variables besides subjective norms such as attitude, religiosity, promotion, and so on.

Subjective norms have a positive and significant influence on purchase intentions. Evidenced by the results of the regression test of 0.386 , with a $t$ value of 11.221 with a significance of 0,000 . Sig value less than 0.05 means that if subjective norms that develop in the respondent environment are positive, then the intention to buy cosmetics that are certified as halal also increases. Furthermore, the F test results amounted to 101,914 with a significance value of 0,000 . This result can be interpreted that subjective norms affect the purchase intention of halal-certified cosmetics.

The second hypothesis testing shows that the value of $\mathrm{R}$ is 0.656 , the value of $\mathrm{R}$ Square is 0.431 , and the adjusted $\mathrm{R}$ Square value is 0.428 . From the value of $\mathrm{R}$ Square, it can be interpreted that $43 \%$ purchase intention is influenced by attitude variables. In other words, $57 \%$ of behavioral intentions are influenced by variables other than attitudes such as subjective norms, religiosity, promotion, and so on.

Attitude has a positive and significant influence on purchase intentions. Evidenced by the results of the regression test of 0.428 , with a t value of 12.301 with a significance of 0.000 . Sig value smaller than 0.05 means that if the respondent's attitude is positive towards halalcertified cosmetics, then the purchase intention also increases. Furthermore, the F test results 
amounted to 151.305 with a significance value of 0,000 . This result can be interpreted that attitude influences the intention to buy halal certified cosmetics.

The third hypothesis testing shows that the value of $\mathrm{R}$ is 0.575 , the value of $\mathrm{R}$ Square is 0.330 , and the adjusted R Square value is 0.327 . From the value of R Square, it can be interpreted that $33 \%$ of purchase intention is influenced by the variable of religiosity. In other words, $57 \%$ of behavioral intentions are influenced by variables other than religiosity, such as subjective norms, attitudes, promotions, and so on.

Religiosity has a positive and significant influence on purchase intentions. Evidenced by the results of the regression test of 0.330 , with a t value of 9,927 with a significance of 0,000 . Sig value smaller than 0.05 means that if the respondent's religiosity is higher, then the purchase intention will also increase. Furthermore, the F test results amounted to 98,537, with a significance value of 0,000 . This result can be interpreted that religiosity affects the intention to buy halal certified cosmetics.

\subsection{Discussion}

The discussion about purchase intention is a complex matter because it is related to cognitive and affective factors. Therefore the discussion about purchase intention will always be accompanied by attitude and subjective norm. In this study, religiosity was added as an independent variable because it discussed halal products.

In this study, the attitude has a positive and significant effect on halal cosmetics purchase intention. The results of this study are in line with previous studies that the attitude of an individual on a product will affect the purchase intention of the product[13], [27], [28]. The results of this study explained that the more positive the consumer's attitude towards halalcertified products, the greater the intention to purchase the product.

This research shows that consumer attitudes on halal-certified products must be shaped by marketers so that intention to purchase rises. Efforts made to improve consumer attitudes need to be made creatively and effectively. Because attitude is the intention-forming variable of established theory, attitude-based marketing programs can be prioritized.

A discussion of other variables in the formation of an intention to purchase is the subjective norm. Subjective norm has a positive and significant effect on halal cosmetics purchase intention. The results of this study are in line with previous studies that the norm that is around individuals will affect the purchase intention of a product[11], [12], [14]. The results of this study explained that the stronger the subjective norm of cosmetics labeled as halal, the stronger the intention to purchase the product.

In addition to attitude, the subjective norm is also an intention formation variable from established theory. Thus, efforts to influence the environment to be more aware of halalcertified cosmetics need to be done by a marketer. The more aware of an environment in halalcertified cosmetic products, the easier it will be for a marketer to make consumers have the intention to purchase.

Religiosity is a variable that has not been widely used in predicting behavior. In this study, religiosity has a positive and significant effect on halal cosmetics purchase intentions. The results of this study are in line with previous studies that high and low religiosity will affect individual intentions[13].

Religiosity is an appropriate variable to be added to behavioral research on halal products. The higher religiosity, a person will become aware of the halalness of a product. Thus, the intention to purchase halal cosmetics will increase if the reliability of individuals will increase. 


\section{Conclusion}

From the results of this study, it can be concluded that the intention to buy halal-certified cosmetics is influenced by subjective norms, attitudes, and religiosity. These results indicate that efforts to find out buying interest can be made by finding information about subjective norms, attitudes, and religiosity that develop in the community.

From this study, several recommendations were made. First, recommendations for academics should develop marketing research in the field of halal certification of micro, small, and medium enterprises engaged in non-food fields. Second, the researcher recommends the government provide intensive halal certification assistance to micro, small and medium enterprises engaged in the non-food sector. Third, to increase the buying interest of the community, non-food processed entrepreneurs should focus on halal certification, because the religiosity of Indonesian Muslim communities is increasingly increasing.

\section{References}

[1] GlobalReligiousFuture, "The Future of World Religions," 2016. [Online]. Available: $\mathrm{http}: / / \mathrm{www}$.globalreligiousfutures.org/.

[2] BPS, "Kewarganegaraan, Suku Bangsa, Agama, dan Bahasa Sehari-hari Penduduk Indonesia," 2010. [Online]. Available:

https://www.bps.go.id/publication.html?Publikasi\%5BtahunJudul\%5D=\&Publikasi\%5BkataKunci $\% 5 \mathrm{D}=$ agama\&Publikasi\%5BcekJudul\%5D=0\&Publikasi\%5BcekJudul\%5D=1\&yt0=Tampilkan.

[3] GlobalReligiousFuture, "Religious Demography: Affiliation," 2017. [Online]. Available: http://www.globalreligiousfutures.org/countries/indonesia\#/?affiliations_religion_id=0\&affiliations _year=2010\&region_name=All Countries\&restrictions_year=2016.

[4] V. Briliana and N. Mursito, "Exploring antecedents and consequences of Indonesian Muslim youths' attitude towards halal cosmetic products: A case study in Jakarta," Asia Pacific Manag. Rev., vol. 22, no. 4, pp. 176-184, 2017.

[5] MUI, "Mengenal Bahan Kosmetika dan Obat-Obatan," 2020. [Online]. Available: http://www.halalmui.org/mui14/main/detail/mengenal-bahan-kosmetika-dan-obat-obatan.

[6] B. L. Yeo, R. H. N. Mohamed, and M. Muda, "A Study of Malaysian Customers Purchase Motivation of Halal Cosmetics Retail Products: Examining Theory of Consumption Value and Customer Satisfaction," Procedia Econ. Financ., vol. 37, no. 16, pp. 176-182, 2016.

[7] S. Bom, J. Jorge, H. M. Ribeiro, and J. Marto, “A step forward on sustainability in the cosmetics industry: A review,” J. Clean. Prod., vol. 225, pp. 270-290, 2019.

[8] I. Ajzen, "The theory of planned behavior," Organ. Behav. Hum. Decis. Process. VO - 50, no. 2, p. 179, 1991.

[9] A. Abd Rahman, E. Asrarhaghighi, and S. Ab Rahman, "Consumers and halal cosmetic products: Knowledge, religiosity, attitude and intention,” J. Islam. Mark., vol. 6, no. 1, pp. 148-163, 2015.

[10] Q. Xie, W. Song, X. Peng, and M. Shabbir, "Predictors for e-government adoption: Integrating TAM, TPB, trust and perceived risk," Electron. Libr., vol. 35, no. 1, pp. 2-20, 2017.

[11] R. Lee, J. Murphy, and L. Neale, "The interactions of consumption characteristics on social norms," J. Consum. Mark., vol. 26, no. 4, pp. 277-285, 2009.

[12] K. Kaushik, N. Kumar Jain, and A. Kumar Singh, “Antecedents and outcomes of information 
privacy concerns: Role of subjective norm and social presence," Electron. Commer. Res. Appl., vol. 32, pp. 57-68, 2018.

[13] J. Bananuka, T. K. Kaawaase, M. Kasera, and I. Nalukenge, "Determinants of the intention to adopt Islamic banking in a non-Islamic developing country: The case of Uganda," ISRA Int. J. Islam. Financ., 2019.

[14] B. Marakarkandy, N. Yajnik, and C. Dasgupta, "Enabling internet banking adoption," J. Enterp. Inf. Manag., vol. 30, no. 2, pp. 263-294, 2017.

[15] N. A. Hasbullah, A. Osman, S. Abdullah, S. N. Salahuddin, N. F. Ramlee, and H. M. Soha, "The Relationship of Attitude, Subjective Norm and Website Usability on Consumer Intention to Purchase Online: An Evidence of Malaysian Youth," Procedia Econ. Financ., vol. 35, no. October 2015, pp. 493-502, 2016.

[16] S. (Charles) Qiu, M. Li, A. S. Mattila, and W. Yang, "Managing the face in service failure: the moderation effect of social presence," Int. J. Contemp. Hosp. Manag., vol. 30, no. 3, pp. 1314 $1331,2018$.

[17] H. (Kelly) Min, J. Park, and Y. Hu, "Toward understanding the attitude measurements in hospitality research,” Int. J. Hosp. Manag., vol. 89, no. April, p. 102567, 2020.

[18] C. Coulson-Thomas, "Learning and behaviour: Addressing the culture change conundrum: Part two," Ind. Commer. Train., vol. 47, no. 4, pp. 182-189, 2015.

[19] M. Ilska, A. Brandt-Salmeri, and A. Kołodziej-Zaleska, "Effect of prenatal distress on subjective happiness in pregnant women: The role of prenatal attitudes towards maternity and ego-resiliency," Pers. Individ. Dif., vol. 163, no. February, 2020.

[20] L. Henn, S. Otto, and F. G. Kaiser, "Positive spillover: The result of attitude change," J. Environ. Psychol., vol. 69, no. April, 2020.

[21] J. D. Valleman, "How To Share An Intention '," Philos. Phenomenol. Res., vol. 57, no. 1, pp. 29 $50,2015$.

[22] R. Casidy, I. Phau, and M. Lwin, "The role of religious leaders on digital piracy attitude and intention,” J. Retail. Consum. Serv., vol. 32, pp. 244-252, 2016.

[23] P. Garg and R. Joshi, "Purchase intention of 'Halal' brands in India: the mediating effect of attitude," J. Islam. Mark., vol. 9, no. 3, pp. 683-694, 2018.

[24] A. J. Morrison and J. S. Black, The character of global leaders, vol. 8. Emerald Group Publishing Limited, 2014.

[25] M. Ramnauth, F. Driver, and P. B. Vial, "Food safety management in the fish industry in Mauritius: Knowledge, attitude and perception," Br. Food J., vol. 110, no. 10, pp. 989-1005, 2008.

[26] R. D. Cooper and S. P. Schindler, Business Research Methods, 12th ed. New York: Mc Graw Hill, 2014.

[27] C. Jayawardhena, "Personal values' influence on e-shopping attitude and behaviour," 2015.

[28] R. Spacey, A. Goulding, and I. Murray, "Exploring the attitudes of public library staff to the Internet using the TAM," J. Doc., vol. 60, no. 5, pp. 550-564, 2004. 